\title{
Przyszłość form konsensualnych w postępowaniu administracyjnym
}

\section{Wprowadzenie}

Stałe zwiększanie się i zróżnicowanie obowiązków współczesnej administracji, konieczność sprostania nieznanym dotąd zadaniom wymusza poszukiwanie alternatywnych form i procedur w stosunku do decyzji i towarzyszącego jej tradycyjnie pojmowanego postępowania jurysdykcyjnego. Współczesne prawo administracyjne rozwija się w kierunku multiplikacji form i procedur przystosowanych do załatwiania spraw określonego rodzaju. Popularność zyskują między innymi formy konsensualne, zakładające - najogólniej rzecz ujmując - zawarcie określonego porozumienia w miejsce władczego i jednostronnego aktu stosowania prawa. Do takich konstrukcji należą: ugoda oraz umowa administracyjna. Intensywny rozwój tej ostatniej daje się zaobserwować w systemach europejskich. Można zauważyć, że na kontynencie wykształciły się dwa modele umowy administracyjnej: francuski, szeroko ujmujący tę instytucję, w ramach której strony umowy dobrowolnie poddają się rygorom prawa administracyjnego, oraz niemiecki, zakładający zastąpienie przez umowę aktu administracyjnego. W podjętej w rodzimej nauce dyskusji na temat umowy administracyjnej w zasadzie nie ma sporu co do konieczności włączenia tej konstrukcji do systemu administracyjnego prawa procesowego ${ }^{1}$. Można zatem sądzić, że jest to tylko kwestią czasu, kiedy przepisy poświęcone umowie administracyjnej staną się częścią

${ }^{1}$ I. Lipowicz, Prawne formy działania administracji publicznej - między stabilizacja a potrzeba przełomu, "Ruch Prawniczy, Ekonomiczny i Socjologiczny” 2016, z. 4, s. 42 i n.; A. Krawczyk, Umowa administracyjna, w: Reforma prawa o postępowaniu administracyjnym. 
Kodeksu postępowania administracyjnego, zwłaszcza że takie próby były już podjęte. Analiza porównawcza dowodzi, że instytucja ta daje się ujmować w języku tekstu prawnego w rozmaity sposób, realizując zarazem różne zapatrywania na jej istotę i znaczenie dla prawa o postępowaniu administracyjnym.

Celem artykułu jest zaprezentowanie umowy administracyjnej jako konstrukcji postępowania administracyjnego funkcjonującej w wybranych porządkach europejskich, a także zwrócenie uwagi na potrzebę uregulowania tej instytucji w rodzimym systemie.

\section{Umowa administracyjna typu francuskiego}

Umowa typu francuskiego stała się popularna przede wszystkim w sprawach gospodarczych, których przedmiotem jest świadczenie usług publicznych kwalifikowanych do kategorii zamówień publicznych. Umowa administracyjna w ujęciu francuskim oraz przyjęte we Francji poglądy na tę instytucję upowszechniły się też w innych systemach, np. Rumunii, Portugalii czy Hiszpanii. Odnotować należy, że okoliczność ta w ostatnim czasie spowodowała we Francji i niektórych państwach południa Europy utratę jej znaczenia, czy wręcz - jak podnoszą niektórzy - wyrugowanie. Do przyczyn tego stanu rzeczy zalicza się uwarunkowania prawa unijnego w zakresie zamówień publicznych, choć - jak się także wskazuje - kontrakty w tych sprawach noszą autonomiczny charakter, jedynie zbliżony do umowy administracyjnej, nie wyczerpując jednak jej znamion w pełni ${ }^{2}$. Obok umów tego rodzaju francuska administracja zawiera z jednostkami również umowy cywilnoprawne, poddane orzecznictwu sądów powszechnych.

Umowa typu francuskiego dochodzi do skutku przez złożenie oświadczeń woli obydwu stron, mocą których poddają one jednocześnie dany kontrakt rygorom prawa administracyjnego. W orzecznictwie i nauce prawa wyodrębniono cechy konstrukcyjne umowy administracyjnej typu francuskiego oraz dostrzeżono zróżnicowanie w obrębie tej formy. Wskazuje się na kilka kategorii przesłanek uznania kontraktu za

Raport zespołu eksperckiego, pod red. Z. Kmieciaka, Warszawa 2016, s. 146 i n., http://www. nsa.gov.pl/raport-ekspercki-kpa.php (dostęp: 18 II 2019).

${ }^{2}$ L.T. Pascariu, Current Guidelines in the Field of Administrative Contracts, "The Annals of The 'Ştefan cel Mare' University of Suceava. Fascicle of The Faculty of Economics and Public Administration" 2010, vol. 10, no. 2(12), s. 278-283. 
administracyjny, które można podzielić na: formalne, oparte na kryterium ustawowym i organicznym, oraz materialne, związane z istnieniem klauzul nadmierności albo wykonywaniem służby publicznej. Pierwszemu z nich - ustawowemu - przypisuje się charakter podstawowy, a zarazem najmniej skomplikowany. Wedle niego za administracyjną należy uznać taką umowę, która w ten sposób oznaczona jest przez prawo, bez pozostawiania miejsca na poszukiwanie innego rezultatu wykładni. Kryterium ustawowe wykorzystywane jest także przez ustawodawcę rumuńskiego, czego przykład stanowi ustawa o zamówieniach publicznych, robotach publicznych i dzierżawie oraz ustawa o dzierżawie majątku publicznego ${ }^{3}$. Przy czym, jak zauważono w doktrynie, administracyjny charakter kontraktu nie musi być wskazany w przepisie ustawy wprost, lecz może zostać z niej "wydobyty” w drodze jego wykładni w toku sporu sądowego ${ }^{4}$.

Kryterium organiczne odwołuje się do jednej ze stron umowy: organu administracji publicznej. Wydaje się, że może chodzić tu zarówno o organ w znaczeniu strukturalnym, jak i funkcjonalnym, a więc o podmiot prawa prywatnego, któremu powierzono wykonywanie zadań publicznych. Ostatnie kryterium odnosi się do zamieszczenia w umowie specjalnych klauzul, uprzywilejowujących będący stroną umowy organ administracji. Bywają one różnie określane: jako „klauzule nadmierności”, "klauzule odwołalności” czy „klauzule wykonywania służby publicznej" ${ }^{\prime \prime}$. Pozostałych, wyróżnianych w nauce prawa, cech charakterystycznych umowy administracyjnej typu francuskiego nie sposób - jak sądzę - zakwalifikować do elementów konstrukcyjnych tej instytucji. Stanowią one raczej ich konsekwencję, nie zaś warunek uznania kontraktu za administracyjny. Zaliczyć do nich można wyróżnione przez R. Le Mestre'a elementy treściowe umowy administracyjnej oraz specyficzne metody wykładni. Autor ten zwrócił uwagę na: zdeterminowaną koniecznością ochrony interesu ogólnego realizowanego przez organ administracji nierówność stron umowy administracyjnej (przewagę uprawnień przysługujących organowi), której szczególnym

${ }^{3}$ Ordonanța de urgență nr. 34/2006 privind atribuirea contractelor de achiziție publică, a contractelor de concesiune de lucrări publice şi a contractelor de concesiune de servicii, nr. 34 din 19 aprilie 2006, Monitorul Oficial nr. 418 din 15 mai 2006, Ordonanța de urgență nr. 54/2006 privind regimul contractelor de concesiune de bunuri proprietate publică, nr. 54 din 28 iunie 2006, Monitorul Oficial nr. 569 din 30 iunie 2006, http:// legislatie.just.ro/Public/DetaliiDocument/73070 (dostęp: 18 II 2019).

${ }^{4}$ L.T. Pascariu, Current Guidelines..., s. 409, i podana tam literatura.

${ }^{5}$ P. Folliard, Droit administratif, Paris 2008, s. 241-242. 
przejawem jest dopuszczalność jednostronnego rozwiązania umowy przez organ administracji za odszkodowaniem dla drugiej strony, ustawowe ograniczenia organu w korzystaniu ze swobody kontraktowania, realizację interesu publicznego przez organ administracji i towarzyszące temu określone cele szczególne, możliwość zabezpieczenia należytego wykonywania obowiązków kontraktowych przez jednostkę karami, obowiązek osobistego wykonywania umowy (cesja dopuszczalna jest wyjątkowo, za zgodą organu), respektowanie równowagi ekonomicznej wzajemnych świadczeń ${ }^{6}$.

Umowa administracyjna może przybierać różne formy i poziomy sformalizowania, od bardzo prostych po kompleksowe, jak w przypadku zamówień publicznych. W ocenie R. Le Mestre'a postanowienia umowy administracyjnej podlegają $w$ interesie publicznym wykładni rozszerzającej $^{7}$. Autor ten zauważył, że problem niemożliwości świadczenia może być w odniesieniu do umowy administracyjnej rozwiązany za pomocą jednej z dwóch teorii. Pierwsza odnosi się do istoty działań władzy publicznej (dosł. czynu księcia, fait du prince) i zakłada, że może ona jednostronnie pogorszyć warunki umowy i z tego powodu być zobowiązana do zapłaty odszkodowania. Z kolei teoria nieprzewidywalności uwzględnia przypadek niedającej się przewidzieć zmiany pierwotnej równowagi kontraktu ze względu na wyjątkowe zdarzenia ekonomiczne. Każda z wymienionych teorii uzasadnia jednostronne rozwiązanie umowy ewentualnie zmiany jej warunków ze względu na ważny interes publiczny ${ }^{8}$.

\section{Niemiecka koncepcja umowy administracyjnej}

W systemie prawa niemieckiego wykształciły się dwa typy umowy administracyjnej: koordynacyjna (między równorzędnymi partnera$\mathrm{mi}$ ) i subordynacyjna (między organem a stroną), ta ostatnia ponadto w odmianach umowy wymiany lub ugody ${ }^{9}$. Umowa administracyjna

${ }^{6}$ R. Le Mestre, Termes du droit administratif, Paris 2006, s. 58-62, cyt. za: L.T. Pascariu, The Distinction of the Administrative Contract from Other Types of Contracts, "The Annals of The 'Ştefan cel Mare' University of Suceava. Fascicle of The Faculty of Economics and Public Administration" 2010, vol. 10, Special Number, s. 408-409.

${ }^{7}$ R. Le Mestre, op. cit., s. 58-62, cyt. za: L.T. Pascariu, The Distinction of the Administrative Contract..., s. 408-409.

${ }^{8}$ Ibidem.

${ }^{9}$ A. Krawczyk, op. cit., s. 146 i n. 
zawierana jest po przeprowadzeniu czynności postępowania administracyjnego. W umowie wymiany jednostka i organ administracji mogą zobowiązać się do wzajemnych świadczeń w celu wypełniania zadań publicznych. Świadczenie wzajemne jednostki musi odpowiadać okolicznościom sprawy i pozostawać w związku rzeczowym ze świadczeniami organu. Ma to zabezpieczać przed wyzbywaniem się władztwa przez organy administracji oraz chronić jednostkę będącą słabszą stroną umowy przed żądaniem od niej nadmiernych i nieuzasadnionych świadczeń. Ustawa niemiecka zawiera rozbudowaną regulację dotyczącą wadliwości umowy. W zależności od momentu ich powstania rodzą skutek nieważności (podstawy analogiczne jak cywilnie rozumiane wady oświadczenia woli oraz uchybienia co do formy czy naruszenie ustawowego zakazu zawierania umowy w określonym zakresie spraw) albo dają podstawę wypowiedzenia umowy bądź sanacji umowy poprzez dostosowanie jej warunków do wymagań ustawowych. Roszczenia z tytułu tych umów poddane są kognicji sądów administracyjnych ${ }^{10}$. W wielu innych systemach europejskich zdecydowano się uregulować umowę administracyjną. Z kolei w tych porządkach, w których dotąd formy tej nie wprowadzono, przedstawiciele nauki dość zgodnie to postulują ${ }^{11}$.

\section{Przykłady poświęconych umowie administracyjnej uregulowań obowiązujących w wybranych państwach europejskich}

\subsection{Metoda regulacji umowy administracyjnej}

W ustawach procesowych państw europejskich dominuje ogólny, wręcz ramowy charakter regulacji poświęconej umowie administracyjnej, co uzasadnia posługiwanie się odesłaniami. Ten sposób konstruowania aktów prawnych bywa poddawany krytyce, choć niewątpliwie jego właściwe zastosowanie sprzyjać może spójności systemu ${ }^{12}$. W poszczególnych porządkach europejskich funkcjonują regulacje zawierające zróżnicowane rozwiązania, wzorowane często na koncepcjach przyjętych w systemie francuskim i niemieckim. Pewnym paradoksem jest

\footnotetext{
${ }^{10}$ Ibidem, s. 146-147.

${ }^{11}$ I. Koprić, P. Kovač, V. Đulabić, J. Džinić, Comparative Study. Legal Remedies in Administrative Procedures in Western Balkans, Branelovica, Montenegro 2016, s. 13.

${ }^{12}$ Ibidem, s. 46.
} 
jednak to, że rozwiązania charakterystyczne dla umowy typu francuskiego mogą przetrwać poza Francja, w której - jak już zasygnalizowano - odchodzi się od zastosowania tej instytucji. Zjawisko to stanowi rezultat implementacji dyrektyw poświęconych zamówieniom publicznym $^{13}$. Transponujące je przepisy zawęziły bowiem zakres zastosowania umowy administracyjnej jedynie do kontraktów publicznych, regulując zarazem szczegółowe kwestie z tym związane. Zbliżony rezultat wywołały podobne zmiany legislacyjne także w niektórych innych państwach, w których regulacjach ustaw procesowych od lat znajdowały się przepisy o umowie administracyjnej. Przykład stanowi art. 1 ust. 1 portugalskiego Kodeksu umów publicznych nr 18/2008 z dnia 28 stycznia 2008 r. (Código dos contratos públicos $)^{14}$. W doktrynie zauważono, że w Portugalii doszło $w$ ten sposób do wyrugowania umowy administracyjnej z systemu prawa procesowego ${ }^{15}$. Analogiczny skutek w Hiszpanii wywołało wejście w życie ustawy nr 30/2007 z dnia 30 października 2007 r. o kontraktach sektora publicznego (Ley de Contratos del Sector Público ${ }^{16}$ ). Warto dodać, że w systemach common law umowę administracyjną utożsamia się z kontraktem zawieranym w celu udzielenia zamówienia publicznego ${ }^{17}$.

Unormowania obce poświęcone umowie administracyjnej koncentrują się wokół kilku istotnych dla tej instytucji zagadnień, do których zaliczyć należy: definicję, strony umowy, warunki dopuszczalności jej

${ }^{13}$ Por. ustalenia Trybunału Sprawiedliwości Unii Europejskiej zawarte w wyroku z 15 V 2003 r., sygn. C-214/00, Komisja Wspólnot Europejskich przeciwko Królestwu Hiszpanii, www.eur-lex.europa.eu (dostęp: 18 II 2019).

${ }^{14}$ Portugalski Kodeks umów publicznych z dnia 28 I 2008 r., http://www.base.gov.pt/ mediaRep/inci/files/base_docs/CCPTextoconsolidadojan2016.pdf(dostęp: 18 II 2019); R.E. de Oliveira, O acto administrativo contratual, "Justiça Administrativa” 2007, N 63, s. 2; J. Pacheco de Amorim, Ambito de aplicação do Codigo Procedimento Administrativo, "Jurisdiçáo Administrativa e Fiscal" Octubro 2016: O Novo Codigo do Procedimento Administrativo, Conferencias do CeJ 2014-2015, http://www.cej.mj.pt/cej/recursos/ebooks/Administrativo_fiscal/eb_novo_CPCA.pdf, s. 43, 55 (dostęp: 18 II 1019); S. Correia, Da Conferencia Procidemental, "Jurisdiçáo Administrativa e Fiscal" Octubro 2016; O Novo Codigo do Procedimento Administrativo, Conferencias do CeJ 2014-2015, http://www.cej.mj.pt/ cej/recursos/ebooks/civil/Direito_Bancario.pdf, s. 118 (dostęp: 18 II 2019); J.C. Vieira de Andrade, Lições de Direito Administrativo, Coimbra 2015, s. 257 i n.

${ }^{15}$ R.E. de Oliveira, op. cit., s. 2; J. Pacheco de Amorim, op. cit., s. 43, 55; S. Correia, op. cit., s. 118; J.C. Vieira de Andrade, op. cit., s. 257 i n.

${ }^{16}$ Diario oficial Boletín Oficial del Estado núm. 261 de 31 de Octubre de 2007.

${ }_{17}$ R.E. Speidel, Judicial and Administrative Review of Government Contract Awards, "Law and Contemporary Problems" 1972, vol. 37, no. 1, s. 63-94; D. Frenzen, The Administrative Contract in the United States, "George Washington Law Review" 1968, vol. 37, no. 2, s. $270 \mathrm{i} \mathrm{n.}$ 
zawarcia, tryb temu towarzyszący, formę, przedmiot umowy, jej treść, skutki zawarcia, ochronę osób trzecich, wykonalność umowy, przesłanki i tryb jej rozwiązania, wady umowy oraz warunki i tryb jej zaskarżalności.

\subsection{Pojęcie umowy administracyjnej}

Wprowadzenie definicji umowy administracyjnej nie jest zasadą; przyjmuje się też różny poziom szczegółowości. Lakonicznie ujęty art. 159 czeskiego Kodeksu postępowania administracyjnego ${ }^{18}$ precyzuje, że umowę administracyjną stanowi dwustronny bądź wielostronny akt, który tworzy, znosi lub zmienia prawa albo obowiązki w sferze prawa publicznego. W art. 95 estońskiej ustawy o postępowaniu administracyjnym ${ }^{19}$ wskazano, że umowa administracyjna to taka, która reguluje stosunki z zakresu prawa administracyjnego. Może być zawarta w celu uregulowania spraw jednostkowych albo nieokreślonej liczby spraw. W myśl art. 3 ust. 4 Kodeksu postępowania administracyjnego Republiki Albanii ${ }^{20}$ umowę stanowi porozumienie, które ustanawia, zmienia albo rozwiązuje stosunek prawa publicznego i którego co najmniej jedną ze stron jest organ administracji ${ }^{21}$. Zgodnie $\mathrm{z}$ art. 22 ust. 1 serbskiej ustawy o ogólnym postępowaniu administracyjnym ${ }^{22}$ jest to dwustronny pisemny dokument, który, o ile jest to dopuszczalne przez przepisy odrębne, może być zawarty pomiędzy organem a strona, który tworzy, zmienia lub rozwiązuje stosunek prawny w sprawie administracyjnej.

\subsection{Warunki zawarcia umowy administracyjnej}

Do warunków zawarcia umowy w większości systemów zalicza się obowiązywanie przepisu szczególnego, który taką możliwość dopuszcza. Takie rozwiązanie przewiduje m.in. art. 159 czeskiego Kodeksu, sekcja

\footnotetext{
${ }^{18}$ Kodeks postępowania administracyjnego z dnia 24 VI 2004 r., Zákon č. 500/2004 Sb., správní ŕád.

${ }^{19}$ Ustawa z dnia 6 VI 2001 r. o postępowaniu administracyjnym, Haldusmenetluse seadus, RT I 2001, 58, 354.

${ }^{20}$ LIGJ Nr. 44/2015 Kodi i procedurave Administrative i Repubikës së Shqipërisë, Fletoren Zyrtare nr. 87, datë 28 V 2015.

${ }^{21}$ I. Koprić, P. Kovač, V. Đulabić, J. Džinić, op. cit., s. 19.

22 Ustawa z dnia 29 II 2016 r., Law on General Administrative Procedure („Official Gazette of RS" No. 18/2016).
} 
92 podsekcja 1 węgierskiej ustawy o ogólnym postępowaniu administracyjnym ${ }^{23}$, art. 97-98 ustawy estońskiej, art. 150 ustawy chorwackiej o ogólnym postępowaniu administracyjnym ${ }^{24}$, art. 98 ust. 2 macedońskiej ustawy o ogólnym postępowaniu administracyjnym ${ }^{25}$, art. 27 ust. 1 czarnogórskiej ustawy o postępowaniu administracyjnym ${ }^{26}$, art. 22 ust. 1 serbskiej ustawy o ogólnym postępowaniu administracyjnym ${ }^{27}$ oraz art. 60 ust. 2 ustawy o postępowaniu administracyjnym obowiązującej w Kosowie ${ }^{28}$. Dodatkowe przesłanki dopuszczalności obejmują na przykład to, by sprawa, w której ma zostać zawarta umowa, mieściła się $\mathrm{w}$ kompetencjach organu - strony umowy. Takie rozwiązanie przyjęto w sekcji 92 podsekcja 1 ustawy węgierskiej, art. 97-98 ustawy estońskiej (tu wyraźnie wskazano, że kompetencja ta musi polegać na zamieszczonej w ustawie delegacji dla organu do zawarcia umowy) oraz art. 98 ust. 2 ustawy macedońskiej. Ustawodawca formułuje niekiedy zastrzeżenie zgodności z prawem, czego przykładem jest art. 20 bułgarskiego Kodeksu postępowania administracyjnego ${ }^{29}$ i art. 150 ust. 1 ustawy chorwackiej, uzależniając możliwość zawarcia umowy od tego, czy jest ona zgodna z prawem. W niektórych ustawodawstwach zamieszczono klauzulę interesu publicznego, warunkując zgodnością z nim dopuszczalność umowy administracyjnej. Przykładem takiego rozwiązania jest art. 98 ust. 2 ustawy macedońskiej, art. 27 ust. 1 ustawy Czarnogóry, art. 159 czeskiego Kodeksu. W ustawie węgierskiej (sekcja 92 podsekcja 1) i chorwackiej (art. 150) nakazano ważenie interesu publicznego $z$ interesem strony. Zasadą jest, że przystąpienie do umowy pozostawiono woli stron. Wyjątkiem jest uregulowanie chorwackie, które w art. 98

${ }^{23}$ Ustawa opublikowana 14 XII 2016 r., 2016. évi CL. törvény az általános közigazgatási rendtartásról.

${ }^{24}$ General administrative procedure act of 27 III 2009, Official gazette Nr. 47/09 of 17 April 2009.

${ }^{25}$ Zakon za opsztata uprawna postapka, Służbien wiesnik 2015/124/10, Law on General Administrative Procedure, Official Gazette No. 124/2015, poz. 3677, s. 10.

${ }^{26}$ Zakon o upravnom postupku, Službeni list Crne Gore, broj 56/2014, 1353, Law on administrative proceedings on $16^{\text {th }}$ December 2014, Official Gazette 56/2014, no. 1353 and amendments.

27 Zakon o opštem upravnom postupku, donet 29. februara 2016, „Službeni Glasnik RS", broj 18/2016, Law on General Administrative Procedure of $29^{\text {th }}$ February 2016, "Official Gazette of RS" No. 18/2016.

${ }^{28}$ Zakon br. 05/L-031 o Opštoj Administrativnoj Proceduri, Službeni List Republike Kosova, Br. 20/21 Jun 2016, Priština; Law on General Administrative Procedure No. 05/L-031, Official Gazette of the Republic of Kosovo, No. 20/21, June 2016, Pristina.

${ }^{29}$ Administrative Procedure Code, State Gazette No. 30/11.04.2006 and amendments. 
ust. 3 przewiduje, że obowiązek w tym zakresie może wynikać z decyzji administracyjnej. Zawarcie umowy administracyjnej może być uzależnione od zgody innego organu, jak w art. 20 ust. 2 ustawy bułgarskiej czy art. 159 czeskiego Kodeksu, który kompetencję tę przewidział dla organu nadrzędnego, a zgoda ma być wyrażana na podstawie oceny umowy pod względem zgodności z prawem i interesem publicznym.

\subsection{Tryb zawarcia umowy administracyjnej}

Nie wszystkie ustawy obce normują tryb zawarcia umowy administracyjnej, a w tych, w których to uczyniono, daje się zaobserwować rozmaite rozwiązania. W ustawie estońskiej na przykład przewidziano, że przepisy poświęcone postępowaniu administracyjnemu należy stosować w sprawach umowy, o ile nie są one sprzeczne z jej naturą. Przy czym umowa wchodzi w życie zgodnie z regulacją przewidzianą dla umów cywilnoprawnych, a jeżeli reguluje większą liczbę spraw - wchodzi w życie na zasadach przewidzianych dla rozporządzeń (art. 101). Jeżeli umowa ogranicza prawa osoby trzeciej, wejście w życie zależy od jej zatwierdzenia przez tę osobę. Z kolei w art. 161 czeskiego Kodeksu wskazano, że umowa dochodzi do skutku po przeprowadzeniu postępowania administracyjnego i zarazem kończy jego tok. Również w czeskim postępowaniu zmierzającym do zawarcia umowy znajdują zastosowanie konstrukcje znane prawu cywilnemu, umowa bowiem dochodzi do skutku poprzez złożenie oferty. Regulacja bułgarska ograniczona jest jedynie do wskazania maksymalnego terminu zawarcia umowy, który wyznaczony jest przez moment wejścia w życie decyzji administracyjnej albo upływ terminu zaskarżenia decyzji do sądu (art. 20 ust. 3).

\subsection{Strony umowy administracyjnej}

Katalog podmiotów, które mogą być stronami umowy, bywa w systemach obcych zróżnicowany. Dopuszcza się bowiem umowy pomiędzy organem a strona, czego przykładem jest regulacja czeska, art. 96 i 98 ustawy estońskiej, art. 20 ust. 1 i 2 ustawy bułgarskiej czy sekcja 92 podsekcja 1 ustawy węgierskiej. Umowy mogą być niekiedy zawierane pomiędzy organami administracji, co przewiduje art. 159 ustawy czeskiej, albo pomiędzy stronami (art. 20 ust. 2 ustawy bułgarskiej). Przy czym w Czechach umowy między jednostkami 
samorządu terytorialnego mogą być zawierane w celu wypełnienia zadań publicznych tylko w sytuacji, gdy przepis szczególny to dopuszcza. Stronami umowy mogą być wedle czeskiego unormowania także strony postępowania administracyjnego, chyba że sprzeciwia się temu przepis prawa albo natura stosunku prawnego. Wówczas zawarcie umowy wymaga zgody organu administracji, która nie będzie wyrażona, jeżeli umowa byłaby sprzeczna z prawem albo interesem publicznym.

\subsection{Składniki treści umowy administracyjnej}

Tylko w niektórych systemach zawarto rozbudowaną regulację odnoszącą się do treści umowy administracyjnej. Przykład takiego rozwiązania stanowi sekcja 92 podsekcja 2 ustawy węgierskiej, zobowiązująca do zamieszczenia $\mathrm{w}$ umowie danych identyfikacyjnych stron, przedmiotu umowy, uzgodnionych środków komunikacji między stronami, podstaw rozwiązania umowy, opisu procedur $\mathrm{w}$ razie naruszenia umowy oraz związanych z tym konsekwencji, a także środków nadzoru nad wykonywaniem umowy. Dodatkowo, jeżeli strona w umowie podejmuje zobowiązania, których nie można nałożyć w drodze decyzji, umowa może być zawarta jedynie wtedy, gdy strona zgodzi się na ponoszenie odpowiedzialności związanej z naruszeniem umowy administracyjnej, w tym egzekucji administracyjnej. Lakonicznie ujęto treść umowy administracyjnej w art. 120 ustawy albańskiej, który wskazuje, że może ją stanowić zobowiązanie wykonania albo zaniechania określonych czynności z zakresu porządku publicznego, oraz w art. 27 ust. 1 ustawy Czarnogóry, zgodnie z którym treścią umowy jest nawiązanie, zniesienie lub zmiana stosunku administracyjnoprawnego. Szczegółowy przedmiot umowy rzadko precyzowany jest w przepisach prawa, a jeżeli już ustawodawca to czyni, to odwołuje się zazwyczaj do pojęcia realizacji zadań publicznych ( $\$ 3$ ust. 1 fińskiej ustawy o postępowaniu administracyjnym ${ }^{30}$, art. 159 czeskiego Kodeksu). Interesujące rozwiązanie zawarto w art. 97-98 ustawy estońskiej, w których wskazano, że umowa może być zawarta w celu załatwienia nieokreślonej liczby spraw.

${ }^{30}$ Hallintolaki (Förvaltningslag), 6.6.2003, Administrative Procedure Act No. 434/2003 on $6^{\text {th }}$ June 2003. 


\subsection{Forma umowy administracyjnej i skutki jej zawarcia}

Zasadą jest brak szczególnych wymagań co do formy umowy, przy czym zwykle wskazywana jest forma pisemna (art. 99 ustawy estońskiej, art. 150 ustawy chorwackiej, sekcja 92 podsekcja 2 ustawy węgierskiej). Ten ostatni przepis zastrzega, że dodatkowe warunki formalne mogą wynikać z przepisów szczególnych. Dla skuteczności umowy może być wymagane - oprócz oświadczeń kontraktujących stron - podjęcie dodatkowych czynności konwencjonalnych w postaci zgody albo zatwierdzenia innego podmiotu. Wśród przyjmowanych rozwiązań powszechny jest obowiązek uzyskania akceptacji organu nadrzędnego, jeżeli organ administracji jest stroną umowy (art. 160 ust. 5 czeskiego Kodeksu), lub organu prowadzącego postępowanie, jeżeli umowę zawierają strony postępowania (art. 20 ust. 2 ustawy bułgarskiej), a także zgody osób trzecich, na których prawa albo obowiązki umowa może wywierać wpływ. Ustawodawstwa obce nie zawsze odnoszą się do skutków zawarcia umowy, ale jeżeli już to czynią, to określają go jako równoważny decyzji administracyjnej. W art. 20 ust. 8 ustawy bułgarskiej wskazano wprost, że umowa zastępuje akt administracyjny, podobnie kwestię tę rozwiązano w art. 97-98 ustawy estońskiej i art. 161 ustawy czeskiej. Z kolei w innych systemach uzależniono zaistnienie takiego skutku od dodatkowych warunków, odnoszących się do prawnej dopuszczalności zawarcia umowy (art. 150 ustawy chorwackiej) oraz lepszej w stosunku do decyzji ochrony interesu publicznego (art. 120 ustawy albańskiej). W większości analizowanych porządków obowiązki wynikające z umowy administracyjnej poddane są bez ograniczeń egzekucji administracyjnej. Specyficzne rozwiązanie zawiera art. 98 ustawy chorwackiej ze względu na to, że umowa może być środkiem wykonywania decyzji administracyjnej. Można zatem powiedzieć, że samo zawarcie umowy zmierza do wykonania decyzji, a wykonanie obowiązków umownych realizuje uprzednio wydaną decyzję.

\subsection{Problem ochrony osób trzecich, na które treść umowy administracyjnej wywiera wpływ}

Zagadnieniu wyrażającemu ideę ochrony osób trzecich poświęca się w porządkach obcych niemało uwagi. W tym zakresie panują rozmaite rozwiązania, od regulacji lakonicznych, jak w ustawach macedońskiej 
(art. 98 ust. 2) i Czarnogóry (art. 27 ust. 1), zastrzegających, że umowa nie może naruszać praw osób trzecich, po istotnie rozbudowane. W art. 150 ustawy chorwackiej i art. 161 czeskiego Kodeksu przewidziano obowiązek zatwierdzenia umowy przez osoby, na których prawa lub obowiązki wywiera ona wpływ. Ponadto przepisy czeskie uzależniają wejście w życie umowy od wyrażenia zgody przez osoby, na które umowa wywiera wpływ. Brak zgody nie tamuje możliwości zawarcia umowy, wówczas bowiem organ może wydać w to miejsce decyzję na podstawie dokumentów mających stanowić podstawę zawarcia umowy. Z kolei w sekcji 92 podsekcji 4 ustawy węgierskiej przewidziano możliwość zażądania zmiany bądź podważenia kontraktu dla osób niebędących stronami umowy, a których umowa dotyczy.

\subsection{Rozwiązanie bądź zmiana warunków umowy administracyjnej}

Warunki oraz tryb rozwiązania albo zmiany umowy kształtowany jest na różnym poziomie szczegółowości. Możliwość rozwiązania lub zmiany dopuszczalna jest $\mathrm{z}$ reguły w przypadku zaistnienia nadzwyczajnych okoliczności, których nie można było przewidzieć w chwili jej zawarcia, jak np. w art. 152 ustawy chorwackiej. Ta swego rodzaju klauzula rebus sic stantibus nie została jednak w ustawie chorwackiej zabezpieczona stosownym roszczeniem procesowym, ponieważ na zmianę albo rozwiązanie umowy wyrazić muszą zgodę obydwie strony. Przepis wyraża jednocześnie zasadę nierówności stron umowy, organowi przysługuje bowiem prawo jednostronnego zerwania albo zmiany umowy w takim przypadku. Według postanowień art. 167 ust. 1 lit. a-e czeskiego Kodeksu rozwiązanie lub zmiana umowy są dopuszczalne za pisemną zgodą wszystkich stron. Przy czym formułowanie propozycji zmiany umowy przez stronę postępowania jest dopuszczalne, jeżeli spełniona jest którakolwiek z rozłącznie ujętych przesłanek: (a) w umowie przewidziano taką możliwość; (b) zaszła zmiana stosunków wpływająca na treść umowy i zakres praw i obowiązków strony umowy; (c) umowa stała się niezgodna z prawem; (d) wymaga tego interes publiczny; (e) w chwili zawarcia umowy istniały fakty nieznane stronie umowy, które gdyby znała, nie zawarłaby umowy tej treści. Zgoda na rozwiązanie umowy następuje z chwilą złożenia oświadczenia przez ostatnią ze stron umowy, a jeżeli było to wymagane - z chwilą zatwierdzenia przez właściwy 
organ. W przypadku braku zgody stron rozstrzyga o tym jednostronnie właściwy organ nadrzędny.

Zgodnie z sekcją 93 podsekcją 1 ustawy węgierskiej zmiana umowy może być zażądana przez stronę umowy, jeżeli pojawią się nowe okoliczności istotne dla celów sprawy albo gdy te istniejące w chwili jej zawarcia zmienią się istotnie. Według art. 102 ustawy estońskiej umowa może być zmieniona albo wygasnąć zgodnie z procedurą przewidzianą dla prawa cywilnego, z uwzględnieniem odrębności przewidzianych w ustawie o postępowaniu administracyjnym. Jeżeli wykonywanie umowy stało się utrudnione po jego wejściu w życie, strona może żądać zmiany umowy zgodnie $\mathrm{z}$ tymi nowymi warunkami. Jeżeli nie jest to możliwe, strona mająca trudności może wnosić o orzeczenie wygaśnięcia umowy przed sądem.

Charakterystyczną dla umowy administracyjnej nierówność stron stosunku prawnego wyrażają przede wszystkim te uregulowania, które uprawniają organ administracji do jednostronnego rozwiązania albo zmiany umowy. Zgodnie z art. 153 ustawy chorwackiej organ administracji może jednostronnie rozwiązać umowę $w$ następujących sytuacjach: (a) we wspomnianym przypadku braku porozumienia co do wprowadzenia zmian w umowie; (b) jeżeli organ lub osoby trzecie ujęte w umowie nie zgadzają się na wprowadzenie zmian; (c) jeżeli strona nie wypełnia obowiązków umownych; (d) jeżeli jest to niezbędne do zapobieżenia poważnego i natychmiastowego zagrożenia życia i zdrowia ludzkiego oraz bezpieczeństwa publicznego, któremu nie można zapobiec innymi środkami, o mniejszych skutkach dla uzyskanych przez jednostkę praw. Rozwiązanie umowy następuje w drodze decyzji wraz z uzasadnieniem przyczyn uchylenia. Decyzja ta jest zaskarżalna do sądu administracyjnego. Jeżeli organ poniósł szkodę z tytułu niewykonania umowy, ma prawo żądać jej naprawienia od strony umowy. Wysokość odszkodowania może być ustalona w decyzji o rozwiązaniu umowy.

Zgodnie z sekcją 93 podsekcją 3 ustawy węgierskiej zmiana umowy przez organ administracji może stanowić konsekwencję naruszenia umowy przez jednostkę. W takim przypadku organ może podjąć również środki zmierzające do wyegzekwowania obowiązków umownych. W Estonii organ może samoistnie zmienić umowę albo ją wygasić, jeżeli jest to absolutnie niezbędne dla zapobiegnięcia poważnej szkodzie dla ważnego interesu publicznego. Tego rodzaju rozstrzygnięcie wymaga uzasadnienia. 
Ustawa obowiązująca w Kosowie w art. 66 ust. 2 dopuszcza jednostronne rozwiązanie umowy ze względu na konieczność uniknięcia poważnej szkody dla interesu publicznego. Strona może uzyskać odszkodowanie za szkodę poniesioną w wyniku tego działania. Zgodnie $z$ art. 66 ust. 3 tego aktu następuje to w drodze decyzji administracyjnej, która musi być sporządzona na piśmie i zawierać uzasadnienie. Ustawa wyodrębnia umowy stanowiące rezultat kompromisu. Rozwiązanie takiej umowy może nastąpić w związku $\mathrm{z}$ interesem publicznym albo jeżeli zmiana prawa czyni ją niezgodną z prawem, bez obowiązku odszkodowawczego, z wyjątkiem takiej zmiany warunków, która wynika z działania lub zaniechania organu, albo jeżeli rozwiązanie nie jest uzasadnione przez obiektywną przyczynę interesu publicznego.

\subsection{Wady umowy administracyjnej}

W porządkach obcych daje się zwykle wyodrębnić katalog wad umowy administracyjnej oraz konsekwencje ich zaistnienia, a także wskazać odpowiednie uprawnienia procesowe. Niektóre ustawy określają przesłanki legalności umowy, czego przykładem jest art. 150 ustawy chorwackiej, który stanowi, że umowa administracyjna nie może być sprzeczna z rozporządzeniem, przepisami obowiązkowymi lub interesem publicznym ani wyrządzać szkody osobom trzecim. Podobnie, lecz od strony pozytywnej, ujmuje to art. 100 ustawy estońskiej. W Estonii umowa administracyjna jest zgodna z prawem, jeżeli jest zgodna z wymaganiami stawianymi decyzjom administracyjnym oraz rozporządzeniom. Kryteria te stosuje się do umowy administracyjnej, o ile nie pozostają one w sprzeczności z jej naturą.

Można również powiedzieć, że panuje gradacja wad umowy administracyjnej. Według postanowień art. 150-151 ustawy chorwackiej umowa jest nieważna, jeżeli jest sprzeczna z decyzja, którą ma wykonywać, lub z przepisami prawa. Nieważność stwierdza sąd administracyjny na skutek skargi jednej ze stron umowy (w tym także organu). Konsekwencją stwierdzenia nieważności jest brak skutków prawnych takiej umowy. Zgodnie z art. 103 ustawy estońskiej umowa jest nieważna, jeżeli zawiera wady, które odpowiednio powodowałyby nieważność decyzji administracyjnej. Jednakże do umowy administracyjnej stosuje się tryb postępowania właściwy badaniu nieważności umów cywilnoprawnych. W Estonii zasadą jest, że umowa, która nie jest 
dotknięta wadą nieważności, ale zawiera wady innego rodzaju, podlega wykonaniu. W art. 104 zamieszczono dodatkowe, alternatywnie ujęte warunki wykonania umowy, do których zaliczono: świadomość strony zawierającej umowę jej niezgodności z prawem albo zawarcie umowy na podstawie błędnych lub niepełnych informacji przedłożonych przez jednostkę bądź uzyskanych na skutek groźby czy oszustwa popełnionego wobec organu albo bezprawnego nań wpływu w jakikolwiek inny sposób. Jeżeli umowa nie jest wykonywana z powodu jej niezgodności z prawem, umowa powinna zostać doprowadzona do stanu zgodności z prawem lub wypowiedziana na podstawie oświadczenia organu. Do chwili upływu terminu wypowiedzenia umowy strony powinny zwrócić sobie, co świadczyły na podstawie umowy, bądź, jeżeli jest to niemożliwe, dokonać stosownej rekompensaty w pieniądzu.

Nieco zaskakującym, ale - jak sądzę - niezwykle użytecznym rozwiązaniem jest recepcja na grunt prawa publicznego znanej prawu cywilnemu konstrukcji klauzuli salwatoryjnej, która może być ujmowana od strony pozytywnej albo negatywnej. W art. 151 pkt 3 ustawy chorwackiej przewidziano, że umowa jest nieważna w całości, jeżeli nieważna jest nawet tylko jej część, z wyjątkiem sytuacji, w której umowa wywoła skutki prawne bez tej części, której nieważność dotyczy. Według postanowień ustawy czeskiej wady umowy powinny prowadzić do wyeliminowania tylko tych postanowień, które są niezgodne z prawem, chyba że natura kontraktu lub warunki jego zawarcia nakazują wyeliminowanie całości umowy.

\subsection{Zaskarżalność umowy administracyjnej}

Zazwyczaj rozbudowana regulacja poświęcona zostaje zaskarżalności umów administracyjnych. Ogólnie rzecz ujmując, umowa może stanowić przedmiot sądowej kontroli. Przedmiotem skargi może stać się również bezczynność organu wyrażająca się w niewykonaniu umowy. Jednocześnie w niektórych systemach uregulowano rozmaicie skonstruowane środki prawne pozwalające na zakwestionowanie umowy przed organem administracji. W art. 12 ustawy chorwackiej dopuszczono na przykład możliwość wniesienia odwołania. Ponadto $\mathrm{w}$ art. 154 tej ustawy przewidziano skargę na niewykonanie umowy do organu sprawującego nadzór nad organem, z którym strona zawarła umowę. Jednocześnie strona może żądać naprawienia szkody 
wywołanej niewykonaniem decyzji. Skarga powinna być rozstrzygnięta w drodze decyzji, na którą służy kolejna skarga, tym razem do sądu. Roszczenie o wykonanie umowy gwarantuje także sekcja 93 podsekcja 4 ustawy węgierskiej. Jeżeli organ nie wywiąże się z umowy administracyjnej pomimo skierowanego doń wezwania, strona może poszukiwać ochrony przed sądem administracyjnym w terminie 30 dni od dnia powzięcia wiadomości o naruszeniu wykonywania umowy.

Interesująco rysuje się rozwiązanie czeskie, przewidujące w art. 169 możliwość badania umowy zgodności z prawem przez organ właściwy do zatwierdzenia umowy. Uruchomienie tego trybu może nastąpić $z$ urzędu albo na wniosek strony - w terminie 30 dni od dnia powzięcia wiadomości o przyczynie wadliwości umowy. W tym zakresie stosuje się przepisy dotyczące weryfikacji decyzji administracyjnych. Konsekwencją ustalenia przez organ niezgodności umowy z prawem jest jej zakazanie w drodze decyzji niezaskarżalnej w trybie administracyjnym. Prawa nabyte przez osoby trzecie na podstawie umowy wyeliminowanej z obrotu prawnego zostają zachowane.

W ustawie serbskiej zdecydowano się na umożliwienie weryfikacji umowy za pomocą znanego innym porządkom prawnym mechanizmu stanowiącego środek prawny od decyzji administracyjnej. Uregulowany bowiem w art. 147-150 tego aktu sprzeciw odpowiada opisanym przez Z. Kmieciaka, a popularnym za granicą konstrukcjom występującym pod nazwą odwołania wewnętrznego w systemach common law, recours gracieux we Francji, "odwołania zastępczego" w Hiszpanii, "reklamacji” w Portugalii, "sprzeciwu” w Holandii oraz we Włoszech ${ }^{31}$. Serbski sprzeciw (prigowor) jest środkiem o charakterze subsydiarnym, przysługującym w przypadku, gdy nie ma żadnego innego środka prawnego (zwłaszcza odwołania). Służy on nie tylko od umów, ale między innymi i od czynności faktycznych ${ }^{32}$. Sprzeciw wnosi się do szefa jednostki, który rozpoznaje go w formie aktu administracyjnego (rešenje), który podlega sądowej kontroli. Kompetencje sądu w odniesieniu do umowy administracyjnej ograniczone są na ogół do orzeczenia nieważności umowy, a żądanie w tym zakresie może zgłosić zwykle każda ze stron umowy ( $\$ 69$ pkt 1 ustawy fińskiej, art. 151 ustawy chorwackiej, art. 128 ustawy bułgarskiej $)^{33}$.

${ }^{31}$ Z. Kmieciak, Odwołania w postępowaniu administracyjnym, Warszawa 2011, s. 44.

${ }^{32}$ I. Kopric, P. Kovač, V. Đulabić, J. Džinić, op. cit., s. 95.

${ }^{33}$ O. Maenpaa, Hallintosopimus (Administrative Contract) (Vammala 1988), Encyclopedia iuridica fennica, Suomalainen lakimiesyhdistys 1994-1999, osa V palstat 227-228. 
Ze względu na to, że regulacja umowy administracyjnej ma zazwyczaj charakter fragmentaryczny, ustawodawca posługuje się rozmaicie ujętymi odesłaniami. W zależności od przyjętej koncepcji ustawodawca odsyła do przepisów prawa materialnego - prawa cywilnego o kontraktach albo do przepisów procesowych odnoszących się do decyzji administracyjnej lub odwołuje się do obydwu tych reżimów jednocześnie. Przykładem tego ostatniego rozwiązania jest Kodeks czeski, który w zakresie umów administracyjnych nakazuje stosować przepisy postępowania administracyjnego przewidziane dla procedury poprzedzającej wydanie decyzji administracyjnej oraz kodeksu cywilnego (z odpowiednimi modyfikacjami) ${ }^{34}$. Podobnie reguluje tę kwestię art. 99 ustawy estońskiej, zobowiązujący do stosowania przepisów o postępowaniu administracyjnym, o ile nie są one sprzeczne $\mathrm{z}$ naturą umowy. Jednocześnie $\mathrm{w}$ art. 105 zamieszczono odesłanie także do przepisów o umowach cywilnoprawnych, $\mathrm{z}$ uwzględnieniem odrębności przewidzianych $\mathrm{w}$ ustawie procesowej. Przykładem odesłania wyłącznie do przepisów prawa cywilnego o kontraktach jest natomiast sekcja 93 podsekcja 5 ustawy węgierskiej.

\section{Aktualne i postulowane rozwiązania rodzime}

Na tle zaprezentowanych porządków obcych unormowania rodzime odnoszące się do form konsensualnych w administracji rysują się ubogo. W aktualnym stanie prawnym w przepisach kodeksu postępowania administracyjnego odnaleźć można jedynie ugodę, której wykorzystywanie należy zresztą do rzadkości. Równolegle obowiązują przepisy szczególne, odnoszące się do rozmaitych umów zawieranych w sferze prawa publicznego w celu realizacji zadań publicznych. Stronami tych kontraktów mogą być albo organy administracji, albo organy i jednostki. Przykładem tych pierwszych są porozumienia dotyczące zarządzania drogami publicznymi, o których mowa w art. 19 ust. 1 ustawy o drogach publicznych $^{35}$. Z kolei do umów pomiędzy jednostkami a organami administracji zaliczyć można kontrakty socjalne, opisane szczegółowo przez I. Sierpowską. Autorka zauważyła, że ów kontrakt stanowi "pisemną umowę zawieraną z osobą ubiegającą się o pomoc, określającą

34 J. Staša, M. Tomǎšek, Codification of Administrative Procedure, "The Lawyer Quarterly" 2012, no. 2, s. 67.

${ }^{35}$ Ustawa z dnia 21 III 1985 r. o drogach publicznych (tekst jedn. Dz.U. 2018, poz. 2068). 
uprawnienia i zobowiązania stron umowy, w ramach wspólnie podejmowanych działań zmierzających do przezwyciężenia trudnej sytuacji życiowej osoby lub rodziny. Celem kontraktu jest określenie sposobu współdziałania w rozwiązywaniu problemów beneficjenta pomocy społecznej oraz wzmocnienie jego aktywności i samodzielności życiowej, zawodowej lub przeciwdziałanie wykluczeniu społecznemu"36. Znacząca liczba regulowanych przepisami prawa publicznego umów zawierana jest $\mathrm{w}$ związku z realizacją programów operacyjnych, polegających na dystrybucji środków na rozmaite przedsięwzięcia w gospodarce i rolnictwie.

Wśród omawianych umów można wskazać te, które wyróżniono w nauce francuskiej. Umowom tym brakuje równorzędności podmiotów, także co do wyboru kontrahenta, który to wybór dokonywany jest jednostronnie przez organ spośród wielu ubiegających się o to kandydatów. Warunki umowy nie podlegają negocjowaniu, zastosowanie znajdują opracowywane przez organy administracji wzorce umowne. Przedmiot umowy obejmuje zazwyczaj wydatkowanie środków publicznych oraz wykonywanie zadań publicznych. Umowa może być rozwiązana lub zmieniona jednostronnie przez organ administracji. Naruszenie umowy przez jednostkę wiąże się z konsekwencjami określonymi w przepisach prawa publicznego, będącymi często sankcjami finansowymi, nakładanymi w drodze decyzji administracyjnej po przeprowadzeniu postępowania administracyjnego. Mimo tych specyficznych cech niektórych kontraktów zawieranych $\mathrm{z}$ administracją $\mathrm{w}$ orzecznictwie oznaczono dość jednolicie charakter tych umów jako cywilnoprawny. W rezultacie spod kognicji sądów administracyjnych wyłączono sprawy z zakresu ustalenia istnienia, wykonania albo rozwiązania umowy o dofinansowanie oraz naprawienie szkód wywołanych niewykonaniem lub nienależytym wykonaniem zobowiązania, natomiast właściwość sądu administracyjnego zachowana jest w sprawach z zakresu sankcji nakładanych z tytułu naruszenia przez beneficjenta warunków dofinansowania ${ }^{37}$.

Dychotomia ta zdaje się stanowić prostą konsekwencję braku regulacji w rodzimym systemie instytucji umowy administracyjnej na poziomie ogólnym. W szczególności brak powszechnie uznanej definicji

${ }^{36}$ I. Sierpowska, Pomoc społeczna jako administracja świadczaca. Studium administracyjnoprawne, Warszawa 2012, s. 318-320.

${ }^{37}$ Por. Z. Kmieciak, Idea procedur administracyjnych trzeciej generacji (na przykładzie postępowania w sprawach dofinansowania projektów w ramach programów operacyjnych), "Państwo i Prawo" 2015, z. 5, s. 3-18. 
tej instytucji utrudnia właściwe rozumienie tej konstrukcji i stosowanie wobec niej adekwatnych narzędzi. W tej sytuacji przeważająca część umów zawieranych $\mathrm{z}$ administracja, i to w sferze prawa publicznego, w sytuacji braku stosownej regulacji została w rodzimym systemie podporządkowana rygorom prawa cywilnego, wbrew - jak się wydaje - istocie tych konstrukcji. Trudno zgodzić się z twierdzeniem, że nazwanie określonej czynności prawnej umową czyni ją automatycznie kontraktem $\mathrm{w}$ rozumieniu przepisów prawa cywilnego. Ułomność konstrukcji cywilistycznych i postępowania cywilnego nie pozwala, jak się wydaje, na rozpatrywanie sporów z zakresu tych umów w ich całokształcie. Trafnie zauważono w nauce obcej, że proces cywilny inkorporuje inne wartości niż te, które są właściwe stosunkom administracyjnym ${ }^{38}$. Można też zastanawiać się, czy sędziom sądów powszechnych nie brakuje stosownego przygotowania pozwalającego na posługiwanie się skomplikowanymi instytucjami prawa publicznego.

Odpowiadając na formułowane od lat postulaty doktryny, w raporcie z prac kierowanego przez Z. Kmieciaka Zespołu do spraw reformy postępowania administracyjnego przygotowano projekt przepisów o umowie administracyjnej, które miały zostać włączone do Kodeksu postępowania administracyjnego ${ }^{39}$. Ostatecznie jednak ten fragment projektu nie znalazł się w ustawie nowelizującej Kodeks z 7 kwietnia 2017 r. ${ }^{40}$ Warto przy tym zauważyć, że projekt Zespołu zakładał umowę subordynacyjną w wersji układu, z wyłączeniem tej, którą nazywa się w ustawie niemieckiej umową wymiany. Uznano bowiem, że ten typ umowy nie przystaje do założeń polskiej procedury administracyjnej ${ }^{41}$. Wspomniane wyżej przykłady dowodzą jednak, że administracja zawiera także umowy, których przedmiotem jest wykonywanie zadań publicznych. Jeżeli pojawiające się swego czasu w mediach deklaracje przedstawicieli władzy publicznej o potrzebie uregulowania instytucji umowy administracyjnej na poziomie ogólnym są nadal aktualne, być może warto rozważyć włączenie do Kodeksu przepisów poświęconych również i tej kategorii umowy. Nie spełnia, jak można sądzić, tych

${ }^{38}$ I. Kopric, P. Kovač, V. Đulabić, J. Džinić, op. cit., s. 147.

${ }^{39}$ M. Rypina, M. Wierzbowski, Umowa $z$ organem w postępowaniu administracyjnym, "Państwo i Prawo" 2010, z. 4, s. 15-27; Z. Kmieciak, Postępowanie administracyjne i sądowoadministracyjne a prawo europejskie, Warszawa 2010, s. 91-92.

${ }^{40}$ Ustawa z dnia 7 IV 2017 r. o zmianie ustawy - Kodeks postępowania administracyjnego oraz niektórych innych ustaw (Dz.U. poz. 935).

${ }^{41}$ A. Krawczyk, op. cit., s. 159-160. 
postulatów unormowanie, które znalazło się w art. 380-382 projektu nowej Ordynacji podatkoweje ${ }^{42}$ a dotyczące tzw. umowy podatkowej. Analiza tego rozwiązania prowadzi do wniosku, że w istocie nie mamy tu do czynienia z umową administracyjna, lecz - posługując się terminologią przyjętą $\mathrm{w}$ porządku niemieckim - z pewną formą funkcjonującego tam układu, poprzedzającego jednak wydanie decyzji. Przedmiotem tej "umowy” ma być uzgodnienie okoliczności, faktów sprawy, nie zaś jej załatwienie, z wyłączeniem potrzeby władczego jej rozstrzygnięcia.

\section{Podsumowanie}

Konstruując regulację poświęconą umowie administracyjnej, warto korzystać z doświadczeń obcych, dopuszczając różne rodzaje umowy, np. przyjmując obie wersje niemieckiej umowy subordynacyjnej. Celowe byłoby unormowanie przesłanek dopuszczalności oraz trybu zawarcia umowy, jej formy, katalogu potencjalnych wad i konsekwencji ich wystąpienia, a także zaskarżalności umowy do sądu, ewentualnie również $\mathrm{w}$ postępowaniu administracyjnym. Definiowanie w przepisie ustawy pojęcia umowy może z pozoru wydawać się zbędne ze względu na zróżnicowanie panujące w obrębie tej instytucji. Jednakże ze względu na utrwaloną kwalifikację umów zawieranych $\mathrm{z}$ administracją jako cywilnoprawnych zabieg taki mógłby być pożądany. Warto wszakże zrezygnować ze zbędnej kazuistyki, by umowa stała się rzeczywistą alternatywą dla decyzji administracyjnej.

Potrzebę uregulowania umowy administracyjnej w Kodeksie postępowania administracyjnego uzasadniają nie tylko wywołujące negatywne dla spójności systemu niedostatki rodzimej regulacji, ale i bogate doświadczenia obce, potwierdzające popularność tej instytucji. Oceny tej nie zmienia obserwowana w niektórych, należących do zdecydowanej mniejszości, porządkach europejskich tendencja zaniku umowy administracyjnej na rzecz kontraktów w przedmiocie zamówień publicznych. Trudno przewidzieć, czy w niedługim czasie w państwach tych nie nastąpi renesans omawianej instytucji, na co wskazywać mogą podnoszone w literaturze głosy krytyczne wobec zaistniałego stanu rzeczy.

${ }^{42}$ Projekt nowej Ordynacji podatkowej, https://legislacja.rcl.gov.pl/docs//2/12314 054/12523386/12523387/dokument351094.pdf (dostęp: 18 II 2019). 


\section{THE FUTURE OF CONSENSUAL FORMS IN ADMINISTRATIVE PROCEEDINGS}

\section{S u m mary}

The article presents the institution of an administrative agreement from the perspective of legal solutions in force in selected European countries. The increase in the number and diversity of tasks performed by the administration and the multitude of conducted proceedings encourage the search for alternative forms of settling a case in relation to an administrative decision. The administrative agreement is one of them. The analysis of foreign regulations confirms that the institution in question belongs to the modern procedural laws. The scope of regulation varies, as do the individual solutions concerning the admissibility and mode of concluding the contract, its subject matter, the mechanisms for removing defects, the grounds for contestability of the contract and its enforceability. It turns out that in individual European orders two patterns of regulation dominate: French and German, although they are subject to significant modifications. The performance of certain public tasks by private parties on the basis of an administrative agreement provides for certain guarantees not only for the parties to the agreement but also for the beneficiaries of those tasks. This particular type of contract allows adequate protection of the public interest. The prevalence of the administrative agreement in Europe prompts the author to formulate a conclusion on the need to include this institution in the home system. The attempt made in the 2017 reform of the Administrative Procedure Code to include in it an administrative agreement was unsuccessful. The provisions on an administrative agreement that were then drafted were intended to give a deeper meaning to mediation, a new institution in administrative proceedings, which is currently not popular. Mediation was to precede the conclusion of an administrative agreement. However, there are no significant obstacles to returning to work on the regulation of this institution, which is so widely used in other European countries, and which is clearly lacking in its home Code.

Keywords: administrative contract - administrative proceedings - comparative administrative proceedings 